\title{
Інгібітор: що слід знати і про що необхідно пам'ятати
}

\author{
B.І. Семеняка' ${ }^{\text {, Г.Б. Рехтман }}{ }^{2}$ \\ 'Державна установа «Інститут гематології та трансфузіології НАМН України», Київ, Україна \\ ${ }^{2}$ Комунальне некомерційне підприємство «Хмельницька обласна лікарня», Україна
}

Гемостатична терапія була і залишається основним методом лікування та профілактики геморагічних ускладнень у хворих на гемофілію, сучасні стратегії якої полягають у застосуванні плазмових та рекомбінантних концентратів факторів згортання крові та препаратів із шунтуючим механізмом дії. Крім замісної терапії, можливе застосування препаратів, дія яких базується на здатності підвищувати активність згортання крові за допомогою заміщення функції відсутніх факторів, так звана нефакторна терапія. Кожен із цих видів терапії має низку переваг та недоліків. Так, факторна терапія супроводжується ризиком розвитку інгібіторної форми гемофілії (ІФГ), що характеризується утворенням інгібіторних антитіл до факторів згортання крові.

Коли факторну терапію лише починали застосовувати, найтяжчими її ускладненнями вважали інфікування гемотрансмісивними інфекціями та інколи - виражені алергічні реакції. Сьогодні, коли концентрати факторів згортання піддаються відповідній вірусній інактивації, найбільш вираженим ускладненням при лікуванні гемофілії вважається розвиток ІФГ [1]. Інгібітори відносять до антитіл імуноглобулінів G, які нейтралізують фактори згортання. Механізм дії інгібітора полягає в тому, що антитіло прикріплюється до FVIII або FIX (рідко - до FVIII та FIX) і нейтралізує чи пригнічує його прокоагуляційну активність, а також стимулює додаткове продукування антитіл. У результаті відбувається зростання активності інгібіторних антитіл у циркулюючій крові пацієнта, що лабораторно проявляється підвищенням титру інгібіторів (рис. 1). Відбувається інактивація факторів згортання крові, що не дозволяє проводити адекватної факторної терапії. Клінічно це проявляється відсутністю або недостатністю гемостатичної відповіді на лікування препаратами факторів згортання крові, які застосовують в рекомендованих протоколами з лікування гемофілії дозах. Тяжкість перебігу гемофілії посилюється, а кровотечі набувають малоконтрольованого характеру [2]. У зв'язку із труднощами контролю епізодів кровотечі у пацієнтів з інгібіторами підвищується ризик серйозних епізодів кровотеч, зокрема в суглоби. Патологічні процеси, які виникають у суглобі внаслідок крововиливу, впливають один на одного, можуть відбуватися паралельно або послідовно і призводять до специфічного ураження суглобів - гемофілічної артропатії, яка $є$ основною причиною інвалідизації та втрати працездатності осіб із гемофілією.

Рисунок 1 Зв'язування інгібітора з FVIII

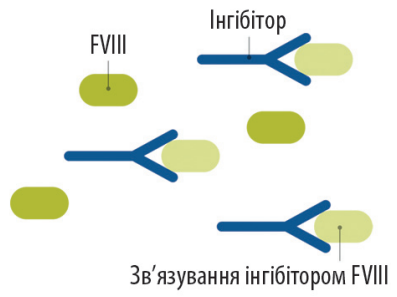

у більшості пацієнтів із ІФГ інгібітор виробляється протягом перших 50-75 днів введення препаратів фактора з максимальним ризиком на 10-20-те введення. Це означає, що інгібітори в основному виробляються у дітей із тяжкою формою гемофілії, хоча вони можуть вироблятися в наступні роки життя і у хворих з легкою або помірною формою, які не потребують настільки частого лікування. Незважаючи на багаторічні дослідження в галузі гематології, причина розвитку ІФГ залишається до кінця не з'ясованою.
Проте розвиток інгібіторів, імовірно, залежить від генетичних, екологічних і пов'язаних із лікуванням факторів, включно з сімейним анамнезом ІФГ, наявністю серйозних дефектів гена фактора згортання крові, етнічною приналежністю хворого (африканський родовід) та раннім інтенсивним лікуванням високими дозами концентратів фактора згортання крові (особливо першими 50 дозами) (рис. 2). Так, дані літератури свідчать, що при тяжкій формі гемофілії А інгібітор розвивається в середньому до 3 років життя, тоді як при середньотяжкій та легкій формі - ближче до 30 років, і часто спостерігається при інтенсивному лікуванні FVIII під час хірургічної операції. Поширеність інгібіторів у популяції хворих на гемофілію А може досягати 13\%, при гемофілії В - до 5\%.

Рисунок 2 Фактори, пов'язані з розвитком ІФГ

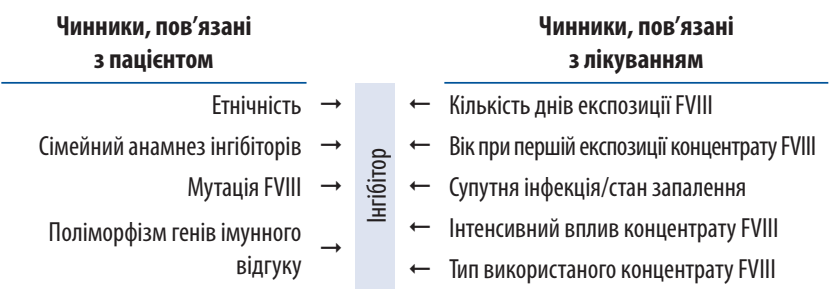

Крім того, на частоту розвитку ІФГ може впливати спосіб лікування пацієнтів із гемофілією. Так, дані літератури свідчать, що профілактичне лікування пов'язане з нижчою частотою розвитку інгібіторів порівняно з лікуванням «за вимогою». Це твердження ґрунтується на гіпотезі про те, що загальний ризик розвитку інгібіторів може відображатися рівнем сигналів, отриманих імунною системою. Відповідно, можна припустити, що лікування «за вимогою» може призвести до частішого розвитку інгібіторів порівняно із профілактичним лікуванням. Так, у дослідженні M. Morado та співавторів на прикладі 50 дітей із тяжкою формою гемофілії А продемонстровано, що у 15 (79\%) із 19 дітей, які лікувалися «за вимогою», вироблялися інгібітори до FVIII, порівняно з 31 пацієнтом, який отримував профілактичне лікування [3]. Результати іншого дослідження за участю 183 пацієнтів із гемофілією продемонстрували, що у $10 \%$ пацієнтів групи, учасники якої отримували профілактичне лікування, розвивалися інгібітори порівняно $з$ 45\% пацієнтів групи лікування «за вимогою» [4].

ІФГ зазвичай діагностують, коли хворий або члени його сім'ї помічають, що гемостатична терапія стає менш ефективною, ніж зазвичай. Ознаками і симптомами розвитку ІФГ $\epsilon$ :

- після введення звичайної дози концентратів фактора згортання крові кровотеча не зупиняється одразу;

- призначене відповідно до протоколів лікування стає все менш ефективним;

- кровотеча все тяжче зупиняється.

Попередній діагноз, встановлений на підставі ознак і симптомів, що вказують на вироблення інгібіторів, необхідно підтверджувати повторними лабораторними дослідженнями. Також інгібітор може бути виявлений під час планового огляду, який проводять $з$ метою періодичної комплексної оцінки стану паці$\epsilon$ нта поза загостренням захворювання. Наявність інгібітора зазвичай підтверджується специфічним аналізом крові, так званим класичним тестом Бетезда чи модифікації Неймеген, який вимірює активність інгібіторів, виявлених у плазмі крові та виражається в одиницях Бетезда (БО/мл) або титрі Бетезда. За 1 одини- 
цю інгібітора (БО) приймають таку його кількість, яка інактивує 50\% доданого FVIII (IX) в 1 мл плазми крові. Для верифікації інгібітора необхідне його повторне визначення з інтервалом в 1 тиж, позитивним вважають результат >0,6 БО (при дослідженні тестом Бетезда в модифікації Неймегена) $[5,6]$.

Активність інгібітора вимірюється в БО/мл і називається титром інгібітора. Чим вищий титр, тим сильніша реакція інгібітора на фактор згортання. На основі титру можна розрізняти інгібітори з високим і низьким титром. Відповідно, осіб з ІФГ необхідно розподіляти залежно від титру інгібітора на пацієнтів із низьким титром/низькореагуючим та високим титром/високореагуючим інгібітором (таблиця).

Відповідно до сучасних гайдлайнів, вироблення інгібітора повинно передбачатися у будь-якого хворого з гемофілією, який не реагує на звичайну гемостатичну терапію. Ризик виникнення інгібітора обернено пропорційний тривалості замісної терапії. Так, для раніше не лікованих пацієнтів ризик розвитку ІФГ становить 30\% у перші 20 днів експозиції, тоді як у пацієнтів, які раніше лікувалися, - <10\% у перші 20-50, 3-5\% - 50-150 та 0,3\% $>150$ днів експозиції [7] (рис. 3). Всесвітня федерація гемофілії (World Federation of Hemophilia - WFH) зазначає важливість регулярного скринінгу інгібіторів у дітей і нещодавно діагностованих дорослих між першою та 50-ю дозою. Навіть після того, як хворі отримають свою 50-ту дозу, вони повинні перевірятися хоча би 2 рази на рік, поки не отримають 150-200 доз, і хоча 61 раз на рік після цього. Тестування на інгібітори має також проводитися повторно перед будь-якими інвазивними хірургічними операціями.

Рекомендації щодо проведення тестування на інгібітор:

- перед плановими інвазивними процедурами;

- коли клінічна чи лабораторна відповідь на застосування концентрату нижче оптимальної;

- до та після заміни препарату;

- через 2-3 тиж після інтенсивного лікування;

- $\geq 5$ днів експозиції чи оперативних втручань;

- у післяопераційний період у разі виникнення клінічно обгрунтованої підозри.

Рисунок 3 Ризик виникнення інгібіторів

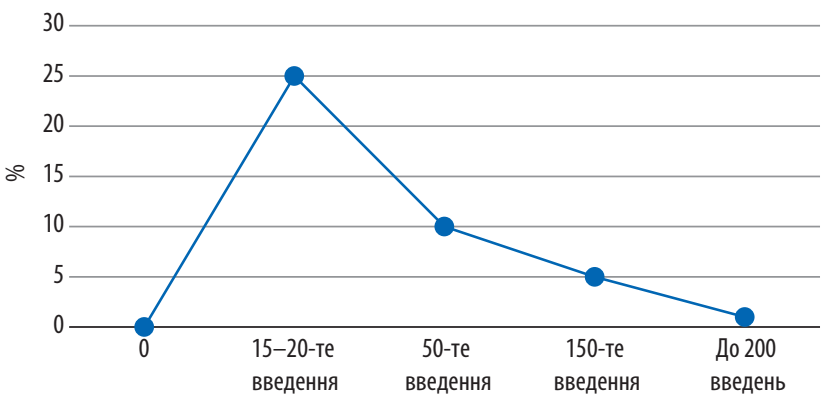

Оскільки при ІФГ відсутня відповідь на традиційну гемостатичну терапію, при менеджменті пацієнтів цієї групи важливим $\epsilon$ раннє визначення інгібітора з метою його ерадикації. Проведення раннього тестування на наявність інгібітора з метою його визначення та ерадикації показане:

- для дорослих осіб із >150 днів експозиції;

- якщо відсутня відповідь на замісну терапію препаратом фактора;
- після оперативних втручань;

- після інтенсивного лікування;

- у дітей інгібітор слід перевіряти через кожні 5 днів до 20-го, кожні 10 між 2-м та 50-м днями експозиції та $\geq 2$ разів на рік до 150 днів експозиції [8].

Таблиця Розподіл пацієнтів із наявністю інгібітора залежно від титру

\begin{tabular}{ll}
\hline Tитр (Б0/мл) & \multicolumn{1}{c}{ Інтерпретація } \\
\hline$<0,6$ & Не виявлено \\
\hline $0,6-<5$ & Низький титр/низькореагуючий інгібітор: \\
& • можна подолати додатковим введенням FVIII \\
& • відсутнє значне підвищення інгібітора після декількох днів введення \\
& препарату \\
& • іноді минає самостійно \\
\hline$\geq 5$ & Високий титр/високореагуючий інгібітор: \\
& • FVIII неефективний \\
& • швидке підвищення титру інгібітора після введення фактора \\
& • титр може знизитися, якщо пацієнт протягом тривалого часу не буде \\
& мати вплив FVIII \\
\hline
\end{tabular}

Таким чином, ІФГ є одним із найсерйозніших ускладнень замісної гемостатичної терапії гемофілії, що не дозволяє проводити адекватне лікування препаратами факторів згортання крові та ускладнює тяжкість клінічного перебігу гемофілії [9]. Своєчасне виявлення інгібітора дозволяє провести корекцію лікування, що сприяє контролю геморагічних ускладнень захворювання, запобіганню розвитку артропатій і поліпшенню якості життя пацієнта.

За підтримки ТОВ «Такеда Україна» VV-MEDMAT-37150

\section{Список використаної літератури/References:}

1. Srivastava A., Brewer A.K., Mauser-Bunschoten E.P. et al. (2013) Guidelines for the management of hemophilia. Haemophilia, 19(1): e1-e47. doi: 10.1111/j.1365-2516.2012.02909.x

2. Teitel J., Berntorp E., Collins P. et al. (2007) A systematic approach to controlling problem bleeds in patients with severe congenital haemophilia $A$ and high-titre inhibitors. Haemophilia, 13(3): 256-263.

3. Morado M., Villar A., Jiménez Yuste V. et al. (2005) Prophylactic treatment effects on inhibitor risk: experiencein one centre. Haemophilia, 11(2):79-83. doi:10.1111/j.1365-2516.2005.00921.x

4. Kreuz W., Gill J.C., Rothschild C. et al. (2005) Full-length sucrose-formulated recombinant factor VIII for treatment of previously untreated or minimally treated young children with severe haemophilia A: results of an international clinical investigation. Thromb. Haemost., 93(3): 457-467. doi: 10.1160/TH03-10-0643

5. AstermarkJ. (2015) FVIII inhibitors: pathogenesis and avoidance. Blood, 125(13): 2045-2051. doi: 10.1182/blood-2014-08-535328

6. Nakar C., Manco-Johnson M.J., Lail A. et al. (2015) Prompt immune tolerance induction at inhibitor diagnosis regardless of titre may increase overall success in haemophilia A complicated by inhibitors: experience of two U.S. centres. Haemophilia, 21(3): 365-373.

7. Wight J., Paisley S. (2003) The epidemiology of inhibitors in haemophilia A: a systematic review. Haemophilia, 9: 418-435

8. Collins P., Baudo F., Huth-Kühne A. et al. (2010) Consensus recommendations for the diagnosis and treatment of acquired hemophilia A. BMC Res. Notes.

9. Scalone L., Mantovani L.G., Mannucci P.M. et al. (2006) Quality of life is associated to the orthopaedic status in haemophilic patients with inhibitors. Haemophilia, 12(2): 154-162. doi: 10.1111/j.1365-2516.2006.01204.x

\section{Information about the authors:}

Semeniaka Volodymyr I. - Candidate of Biological Sciences, Senior Research Officer of the Department of Surgical Hematology and Hemostasiology, SI «Institute of Haematology and Transfusiology of NAMS of Ukraine», Kyiv, Ukraine. Google Scholar ID: scholar.google.com.ua/ citations? user=S2_PSBQAAAAJ\&hl=ru

Rekhtman Hryhoriy B. — Head of the Hematology Department of Khmelnytsky Regional Hospital, Ukraine.

\section{Address for correspondence:}

Volodymyr Semeniaka

02000, Kyiv, Maxim Berlinsky str., 12

E-mail: siemleon@meta.ua 


\section{ТЕСТОВІ ЗАПИТАННЯ}

(один або декілька правильних варіантів відповідей на кожне запитання)

1. Основним методом лікування та профілактики геморагічних ускладнень у хворих на гемофілію без інгібітора $\epsilon$ :

$\square$ факторна та нефакторна терапія

$\square$ глюкокортикостероїди

$\square$ індукція імунної толерантності

$\square$ усі відповіді правильні

2. ІФГ характеризується:

$\square$ утворенням інгібіторного антитіла до факторів згортання крові

$\square$ утворенням антикоагулянтного комплексу гепарин/антитромбін

口 продукцією ендотелієм тканинного активатора фібринолізу

$\square$ усі відповіді правильні

3. Визначте фактори ризику, пов'язані з розвитком інгібітора:

$\square$ сімейний анамнез ІФГ

$\square$ інтенсивне лікування концентратами фактора згортання крові у високих дозах

$\square$ кількість днів експозиції

$\square$ усі відповіді правильні

4. Механізм дії інгібітора полягає в тому, що:

$\square$ антитіло прикріплюється до FVIII або FIX і нейтралізує його

$\square$ антитіло фіксується на ендотелії до антикоагулянтного комплексу гепарин/антитромбін

$\square$ антитіло сприяє продукції оксиду азоту як фактора вазодилатації

$$
\text { усі відповіді правильні }
$$

5. Визначте ознаки та симптоми ІФГ:

$\square$ кровотеча після введення звичайної дози концентратів фактора згортання крові не зупиняється одразу

$\square$ факторна терапія, яка допомагала раніше, стає все менш ефективною

$\square$ кровотеча все тяжче зупиняється

$\square$ усі відповіді правильні

6. Наявність інгібітора підтверджується специфічним аналізом крові:

$\square$ тестом Бетезда чи його модифікацією Неймеген

$\square$ кількість фібриногену

$\square$ тромбіновий час

$\square$ протромбіновий час за Quick

7. Коли рекомендовано проводити тестування на інгібітор?

$\square$ перед плановими інвазивними процедурами

$\square$ коли клінічна чи лабораторна відповідь на застосування концентрату нижча оптимальної

$\square$ до та після заміни препарату

$\square$ усі відповіді правильні

8. Скринінг на наявність інгібіторів рекомендовано проводити:

$\square$ між 1-ю та 50-ю дозою

$\square$ при виникненні простудних захворювань

$\square$ через день

$\square$ лише у дітей віком $<6$ років

\section{Для отримання сертифіката дайте відповідь на тестові запитання в режимі on-line на сайті журналу www.umj.com.ua або надішліть ксерокопію сторінок з відповідями разом з контактною інформацією за адресою: 01001, Київ-1, a/c «В»-82, ТОВ «МОРІОН»}

ПІБ
Поштова адреса: індекс
область
район
місто
вулиця
будинок
квартира

